\title{
Invasibility and recoverability of a plant community following invasion depend on its successional stages
}

\author{
Hongwei $X u^{1,3,4,}$, Zemin $A i^{2, \dagger}$, Qing $Q u^{1,3,4}$, Minggang Wang ${ }^{5}$, Guobin $\operatorname{Liu}^{1,3,4}$, Sha Xue ${ }^{1,3,4, *}$ \\ 1 State Key Laboratory of Soil Erosion and Dryland Farming on Loess Plateau, Institute of Soil and Water Conservation, Chinese Academy of \\ Sciences and Ministry of Water Resources, Yangling 712100, China \\ 2 College of Geomatics, Xi'an University of Science and Technology, Xi'an, Shaanxi 710054, China \\ 3 Institute of Soil and Water Conservation, Northwest A \& F University, Yangling, 712100, China \\ 4 University of Chinese Academy of Sciences, Beijing 100049, China \\ 5 Research Center of Forest Management Engineering of State Forestry and Grassland Administration, Beijing Forestry University, \\ Beijing 100083, China
}

H I G H L I G H T S

- Exotic species cannot obtain more biomass when growing in new areas.

- The invasion ability of the exotic species decreased following succession.

- The recovery ability of native species increased following succession.

- Our study can strengthen our understanding of invasion and restoration ecology.

\section{ARTICLE INFO}

Article history:

Received February 5, 2021

Revised April 9, 2021

Accepted April 29, 2021

Keywords:

Invasion advantage

Recovery advantage

Plant growth

Exotic species

Grass

Greenhouse experiment
GRAPHICAL ABSTRACT

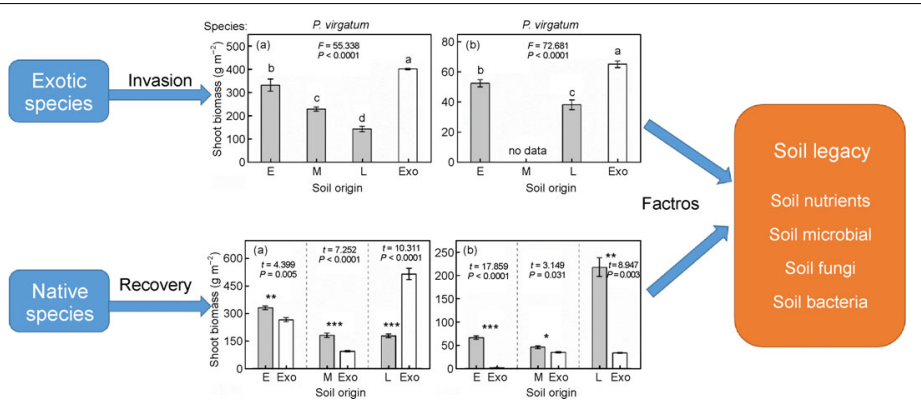

\section{A B S TR A C T}

Exotic species invasion represent important causes of harming the structure, function, and ecological environment in ecosystems. Yet, knowledge remains limited on the invasibility (invasion advantage of exotic species) and recoverability (recovery ability of native species) of a plant community following invasion depend on its successional stages. We selected three grasses of Setaria viridis, Artemisia gmelinii, and Bothriochloa ischemum representing early (E), middle (M), and late $(L)$ successional species, respectively. Meanwhile, the grasses of Panicum virgatum was selected to represent exotic species (invasion species). Three types of soil were collected to treat the three $E, M$, and $L$ successional species, and one type of soil was collected to treat the exotic species. We compared the performance of the three native plant species and one exotic species grown in their "own" and "other" soils in a 2-year greenhouse experiment. Our study showed that exotic species performed better in soils of $E$ and $M$ successional species than in the soil of $L$ successional species. After exotic species removed, E and M successional species exhibited poor growth in the soil of exotic species, while that of $L$ successional species performed poor in field exotic species soils, but performed better in soils disturbed by exotic species. Our study demonstrated that the invasibility and recoverability of native plant communities changed with vegetation succession.

(c) Higher Education Press 2021

\section{Introduction}

* Corresponding author

E-mail address: xuesha100@163.com (S. Xue)

†These authors contributed equally to this work.
Invasion by exotic species has become an important factor in destroying global biodiversity (Guido and Pillar, 2017). After 
exotic species invade new habitats, they spread under appropriate environmental conditions, interfering with and harming the structure, function, and ecological environment of invaded ecosystems (Divíšek et al., 2018; Murugan et al., 2020). Chemical or mechanical control is usually used to combat the negative effects of exotic species invasions on biodiversity and the environment (Kettenring and Adams, 2011), with the aim of restoring affected native plant communities (Flory and Clay, 2009a). Meanwhile, some areas, such as the Loess Plateau in China, have introduced exotic species to restore the damaged vegetation and ecological environment (Ma et al., 2011).

Exotic species invasions are highly complex (Lososova et al., 2015; Murugan et al., 2020); thus, it is important to evaluate the smoothness of exotic species invasions to elucidate the mechanisms involved and potential magnitude. The success of exotic species invasions is affected by regional climate and the soil environment (Divíšek et al., 2018). Exotic species preferentially invade native plant communities that have multiple nutrient utilization strategies and growth habits (Zhang et al., 2020). Nevertheless, studies have shown that exotic species invade native plant communities with similar nutrient utilization strategies and microbial adaptability to guarantee establishment and persistence (Lososova et al., 2015). Thus, systematic studies are required on the type of native plant communities that can be invaded by exotic species.

Secondary succession is the process of restoration and reconstruction of degraded ecosystems after the natural ecosystems are disturbed (Krishna et al., 2020). In this process, the compositions of the plant community and its environment produce an orderly developmental change in a certain direction (Li et al., 2015). In the succession sequence, species at different stages of succession have different life forms and nutrient utilization strategies (Kardol et al., 2006). Exotic species are generally more likely to invade young plant communities than mature plant communities (Flory and Clay, 2009b). Early- to mid-succession species are considered young plant communities, with high nutrient requirements. Consequently, they have "expendable" nutrient utilization strategies and belong to unstable communities that are easily damaged by the environment, with low resistance and resilience stability (Ress et al., 2001). Species at later stages of succession tend to be perennials with large rhizosphere ranges. They have a competitive advantage in nutrient absorption and "durable" nutrient utilization strategies ( $\mathrm{Li}$ et al., 2015), with strong resistance and recovery stability (Ress et al., 2001). However, while exotic species invasions are affected by the habitat conditions of plants (Lososova et al., 2015), the stage of secondary succession (early, middle, late) most vulnerable to invasion remains unclarified.

Studying the recovery of native species after removing exotic species could improve our overall understanding of invasive species ecology and provide theoretical support for the restoration of native species in invaded areas. The removal of exotic species is an important challenge, because we must assess the effect to the plant community after removal and consider the potential risk of secondary invasions (Guido and Pillar, 2017). Exotic species often reinvade after being removed, because of residual effects on soil facilitating re-invasion (Love and Anderson, 2009). Recovery has been examined by cutting invasive species in invaded plant community and comparing growth characteristics with plants in native areas (Guido and Pillar, 2015). Love and Anderson (2009) showed that the native plant community cannot recover after removing exotic species, whereas Guido and Pillar (2017) showed that different clipping methods (onetime cutting versus regular cutting) affect the growth of native plant species differently. Evaluation of plant-soil feedback showed that the soil of exotic species exhibits neutral feedback on the biomass of native species (Shannon et al., 2014). However, the stage of secondary succession (early, middle, late) most capable of recovering after exotic species are removed needs clarifying.

Thus, here, we evaluated the invasiveness of exotic species to native grassland communities, and the ability of these communities to recover, at different stages of secondary succession. For different stages of secondary succession, we explored (1) the invasiveness of exotic species on native plant communities (termed as invasibility) at different stages of secondary succession; (2) the ability of invaded native communities to recover from exotic species invasions (termed as recoverability), and the role of exotic species soil legacy on the recovery process; and (3) the extent to which exotic species invasibility and native species recoverability are influenced by the stage of succession. Therefore, we hypothesized that (1) exotic species can successfully invade native plant community soil but perform better when growing in their own soil than in native plant community soil; (2) the invasion ability of the exotic species decreases following the succession; and (3) the late-succession species would have stronger recoverability after exotic species removal than earlyand mid-succession species.

\section{Methods}

Setaria viridis (abbreviated as Sv), Artemisia gmelinii (Ag), and Bothriochloa ischemum (Bi) were selected as representative plants of early, middle, and late successional species, respectively. These three native species are the dominant grass species of secondary succession on the Loess Plateau. Panicum virgatum (Pv) was selected as the exotic species. Pv is a perennial $\mathrm{C} 4$ gramineous plant that is native to North America and Central America and has been grown as an energy plant since 1990, owing to its developed root system, high productivity, and strong ecological adaptability. In 1990, the Institute of Soil and Water Conservation, Chinese Academy of Sciences, and Ministry of Water Resources began introducing Pv in the Loess Plateau to restore the local ecological environment. This plant showed strong adaptability to extreme climatic conditions of high temperature and 
drought, with good soil and water conservation benefits (Ma et al., 2011).

\subsection{Seed and soil collection}

In this study, five sample sites (minimum of $20 \mathrm{~m} \times 20 \mathrm{~m}$; the distance between any two sites was greater than $500 \mathrm{~m}$ ), located at Ansai Research Station of the Chinese Academy of Sciences $\left(36^{\circ} 51^{\prime} \mathrm{N}, 109^{\circ} 19^{\prime} \mathrm{E}, 1068-1309 \mathrm{~m}\right.$ above sea level [a.s.I.]), were selected for each plant species. This area belongs to the typical vegetation restoration area in China, and these sample sites are located in the long-time observation sites. The annual average precipitation and temperature of this area are $483 \mathrm{~mm}$ and $8.8^{\circ} \mathrm{C}$, respectively. The soil type of this area is loess soil.

The seeds of the four plant species were obtained from adult plants at sampling sites. Soils were collected using the spade from the same location as the seeds, from April 25 to 30,2015 . Soil was collected from the rhizosphere from the $0.05-0.20 \mathrm{~m}$ layer, after removing ground litter and soil in the 0-0.05 m layer. The soil samples were quickly brought to the laboratory, passed through a $5 \mathrm{~mm}$ mesh for removing large litter and debris from the soil, mixed evenly, and stored at $4^{\circ} \mathrm{C}$ for pot planting. Average chemistry and microbial soil properties for the different field soil sources are presented in Table 1.

\subsection{Experimental set-up}

The experiment was carried out in the State Key Laboratory of Soil Erosion and Dryland Farming on the Loess Plateau, Institute of Soil and Water Conservation, Chinese Academy of Sciences and Ministry of Water Resources $\left(34^{\circ} 12^{\prime} \mathrm{N}\right.$, $108^{\circ} 07^{\prime} \mathrm{E}, 530 \mathrm{~m}$ a.s.I.). The average annual temperature and precipitation are $12.9^{\circ} \mathrm{C}$ and $637.6 \mathrm{~mm}$, respectively.

Pots were round containers (diameter $\times$ height: $0.15 \mathrm{~m} \times$ $0.20 \mathrm{~m}$ ). One kilogram of crushed stones (diameter about $0.01 \mathrm{~m}$ ) was added to each pot to prevent soil structural damage and soil material dispersion caused by watering. A plastic tube (diameter $\times$ height: $0.01 \mathrm{~m} \times 0.25 \mathrm{~m}$ ) was inserted as a watering channel in the pot, which terminated above the crushed stones. A piece of paper was added to separate the soil and crushed stones.

The germination rate of the seeds was measured before the experiment and was found to exceed $90 \%$. Briefly, the seeds were sterilized with $2 \%$ sodium hypochlorite for $1 \mathrm{~min}$ and then rinsed with deionized water four times. The seeds were placed in a Petri dish with two layers of filter paper (10 seeds per Petri dish, 3 replicates for each treatment). The Petri dish was surface-sterilized with $70 \%$ ethanol and then placed in an incubator at $25^{\circ} \mathrm{C}$ for culture. Fifteen days after seed germination, the germination rate of the seeds was determined.

\section{Experiment 1}

This experiment was conducted on May 4, 2016. Four types of field soil were collected to treat the three early, middle, and late successional species (referred to as E, M, and L soils, respectively), plus the exotic species (Exo). To examine the performance of the exotic species $\mathrm{Pv}$ in all three soils, $\mathrm{Pv}$ was grown in each of the soil types (Figure 1, red dotted line). To compare the performance of the three native species in their own soil and exotic soils, Sv was grown in E soil, Ag was grown in $\mathrm{M}$ soil, and $\mathrm{Bi}$ was grown in $\mathrm{L}$ soil. These species were compared with the same species grown in Exo soils (Figure 1, blue dotted line). There were 10 replicates for each plant species grown in each soil types. As the bare control, five pots with each soil type and no plants were prepared. 120 pots were used in this phase.

For the planting process, $2.8 \mathrm{~kg}$ soil samples (based on dry weight) were weighed and put in pots. The total weight (including pot, crushed stones, plastic tube, and soil samples) of each pot was recorded for later water control. Thereafter, approximately 10 plant seeds were evenly sown in the pots. After sowing, sufficient water was added to allow seed germination, and the seed germination and soil humidity were regularly observed. Two weeks later, the seedlings were thinned until four plants per pot remained for the field investigation. After thinning, regular watering and management were implemented. Water control was conducted twice a week (to be $80 \%$ of field capacity). The position of pots was changed weekly to limit any effect of microclimate on plant growth. After 4 months, four pots containing uniformly grown plants were selected to collect plant and soil samples for each treatment. The roots were removed from each pot. The soil was homogenized and returned to the same pot of the same treatment.

Experiment 2

This experiment was conducted on May 4, 2017. After

Table 1 Average chemistry and microbial soil properties of field soils.

\begin{tabular}{lccccccc}
\hline Soil origin & $\mathrm{SOC}\left(\mathrm{g} \mathrm{kg}^{-1}\right)$ & $\mathrm{TN}\left(\mathrm{g} \mathrm{kg}^{-1}\right)$ & $\mathrm{TP}\left(\mathrm{g} \mathrm{kg}^{-1}\right)$ & $\mathrm{AP}\left(\mathrm{mg} \mathrm{kg}^{-1}\right)$ & $\mathrm{AN}\left(\mathrm{mg} \mathrm{kg}^{-1}\right)$ & $\left.\mathrm{MBC}_{(\mathrm{mg} \mathrm{kg}}^{-1}\right)$ & $\mathrm{MBN}\left(\mathrm{mg} \mathrm{kg}^{-1}\right)$ \\
\hline $\mathrm{E}$ & 5.53 & 0.62 & 0.54 & 1.65 & 46.36 & 211.04 & 9.96 \\
$\mathrm{M}$ & 5.28 & 0.54 & 0.52 & 1.53 & 51.41 & 98.33 & 8.46 \\
$\mathrm{~L}$ & 5.29 & 0.51 & 0.49 & 0.91 & 44.58 & 201.49 & 9.94 \\
Exo & 4.79 & 0.51 & 0.55 & 1.65 & 60.94 & 221.25 & 13.11 \\
\hline
\end{tabular}

Notes: E, early- succession field soil. M, middle- succession field soil. L, late- succession field soil. Exo, exotic species field soil. SOC, soil organic carbon. TN, soil total nitrogen. TP, soil total phosphorus. AP, soil available phosphorus. AN, soil available nitrogen. MBC, soil microbial biomass carbon. MBN, soil microbial biomass nitrogen. 


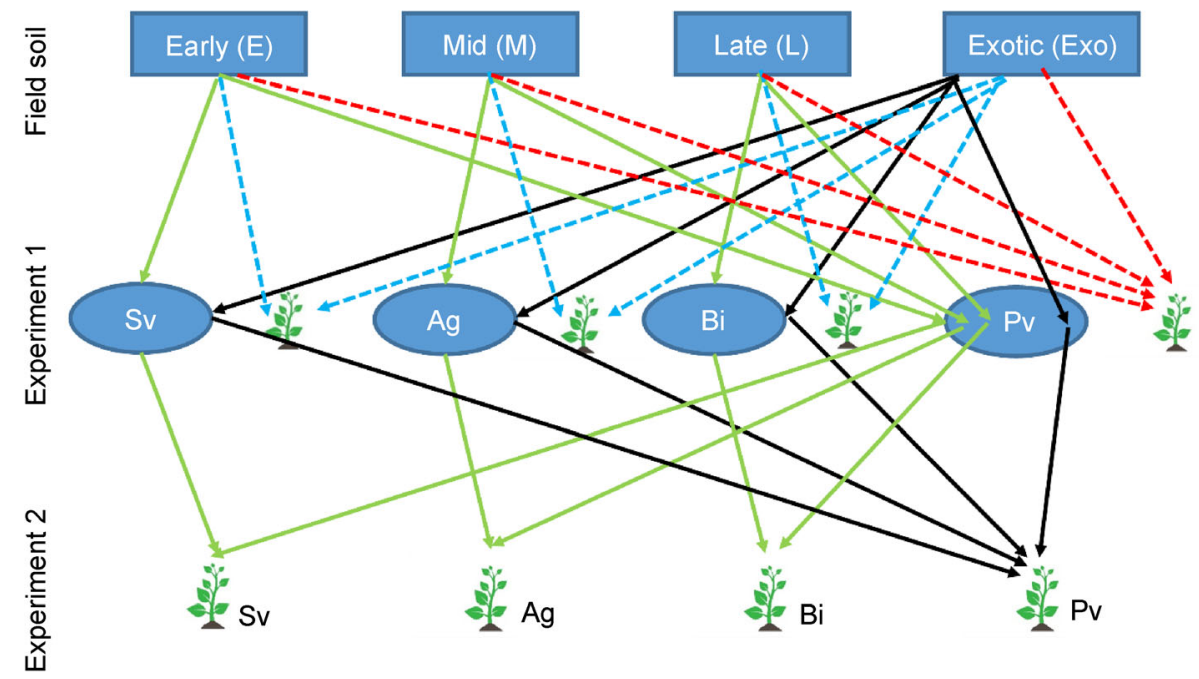

Fig. 1 Experimental design and planting scheme. Experiment 1: field soil from early succession (E) was placed in pots for Setaria viridis (Sv) cultivation; field soil of middle succession (M) was placed in pots for Artemisia gmelinii (Ag) cultivation; and field soil of later succession (L) was placed in pots for Bothriochloa ischemum (Bi) cultivation (see blue dotted line); field soil of exotic species (Exo) was grown in pots for $\mathrm{Sv}, \mathrm{Ag}, \mathrm{Bi}$, and Panicum virgatum (Pv) cultivation (see red dotted line), with 10 replicates. Experiment 2: Pv was grown in soils of native species ( $\mathrm{Sv}, \mathrm{Ag}$, and $\mathrm{Bi}$ ) and in its own soil originating from Exo field soils (see black solid line); native species $\mathrm{Sv}, \mathrm{Ag}$, and $\mathrm{Bi}$ were grown in their own soils and in soils of exotic species originating from the field soils of these native species (see green solid line). All plants were grown for four months.

harvesting the plant species in Experiment 1, the soils were collected and used to assess the recovery of native species following disturbance by exotic species and the invasion of exotic species following disturbance by native species. To determine the invasiveness of exotic species after disturbance by native species, $\mathrm{Pv}$ was grown in soils created from native species ( $\mathrm{Sv}, \mathrm{Ag}$, and $\mathrm{Bi}$ ) versus being grown in its own soils originating from Exo field soils (referred to as Exo-Sv, Exo-Ag, and Exo-Bi vs. Exo-Pv, respectively) (Figure 1, black solid line). To determine the recovery of native species following disturbance by exotic species, Sv, Ag, and Bi were grown in their own soils versus being grown in soils created from exotic species originating from the field soils of these native species (E-Sv vs. E-Pv; M-Ag vs. M-Pv; L-Bi vs. L-Pv, respectively) (Figure 1, green solid line). There were five replicates for each plant species grown in each soil. Planting and management methods were the same as in Experiment 1. Plants were grown for 4 months. Four pots of uniformly grown plants were selected from each treatment for plant and soil samples.

\subsection{Plant biomass harvest and soil sample collection}

The shoots were clipped along the soil surface after removing soil and dust from the plant. The entire root system was then dug out from the pot after removing surface debris. The roots were rinsed with distilled water. The shoot and root of each plants was weighed after drying to a constant weight at $70^{\circ} \mathrm{C}$.

After collecting the roots, the soil from each pot was mixed as our soil samples. Each soil sample was sieved through a
$2 \mathrm{~mm}$ mesh to remove visible stones, litter, and debris. The soil sample was then divided into three parts for different analyses. The first part was stored in a $-80^{\circ} \mathrm{C}$ refrigerator until analyses of soil microbial community structure and diversity. The second part was stored in a $4^{\circ} \mathrm{C}$ refrigerator and was used to determine soil enzyme activity and soil microbial biomass. The third part was naturally separated and was used to analyze soil physicochemical properties.

\subsection{Chemical and biological analyses}

Soil organic carbon (SOC) and plant carbon concentrations were determined using the Walkley and Black method (Nelson and Sommers, 1982). Soil total nitrogen (TN) and plant nitrogen concentrations were determined using the Kjeldahl method (Bremner, 1982). Soil total phosphorus (TP) and plant phosphorus concentrations were estimated using the molybdenum blue method (Schade et al., 2003). Soil available nitrogen (AN) content was determined using the Kjeldahl method (Bremner, 1982). Soil available phosphorus (AP) was extracted with 0.5 $\mathrm{M} \mathrm{NaHCO}_{3}$ (Olsen and Sommers, 1982).

Soil microbial carbon (MBC) and microbial nitrogen (MBN) were measured by the chloroform fumigation-extraction method (Vance et al., 1987). The soil enzymes activities of $\beta-1,4$-glucosidase (B-G), $\beta-1,4-N$-acetylglucosaminidase ( $N$ $A G)$, and acid phosphatase (A-P) were determined using a method developed by Saiya-Cork et al. (2002).

Total bacterial DNA was extracted from samples using the Power Soil DNA Isolation Kit (MO BIO Laboratories) according to the manufacturer's protocol. DNA quality and quantity 
were assessed using ratios of $260 \mathrm{~nm} / 280 \mathrm{~nm}$ and $260 \mathrm{~nm} /$ $230 \mathrm{~nm}$. DNA was then stored at $-80^{\circ} \mathrm{C}$ until further processing. The $\mathrm{V} 3-\mathrm{V} 4$ region of the bacterial $16 \mathrm{~S}$ rRNA gene was amplified with the common primer pair (forward primer, 5'-ACTCCTACGGGAGGCAGCA-3'; reverse primer, 5'-GGACTACHVGGGTWTCTAAT-3') combined with adapter sequences and barcode sequences. PCR amplification was performed in a total volume of $50 \mu \mathrm{L}$, which contained $10 \mu \mathrm{L}$ buffer, $0.2 \mu \mathrm{L}$ Q5 High-Fidelity DNA Polymerase, $10 \mu \mathrm{L}$ High GC Enhancer, $1 \mu \mathrm{L}$ dNTP, $10 \mu \mathrm{M}$ of each primer, and $60 \mathrm{ng}$ genome DNA. Thermal cycling conditions were as follows: initial denaturation at $95^{\circ} \mathrm{C}$ for $5 \mathrm{~min}$, followed by 25 cycles at $95^{\circ} \mathrm{C}$ for $1 \mathrm{~min}, 50^{\circ} \mathrm{C}$ for $1 \mathrm{~min}$, and $72^{\circ} \mathrm{C}$ for $1 \mathrm{~min}$, with a final extension at $72^{\circ} \mathrm{C}$ for $7 \mathrm{~min}$. The PCR products from the first PCR step were purified through VAHTSTM DNA Clean Beads. A second round PCR was then performed in a $40 \mu \mathrm{L}$ reaction, which contained $20 \mu \mathrm{L} 2 \times$ Phusion HF MM, $8 \mu \mathrm{L}$ $\mathrm{dd}_{2} \mathrm{O}, 10 \mu \mathrm{M}$ of each primer, and $10 \mu \mathrm{L}$ PCR products from the first step. Thermal cycling conditions were as follows: initial denaturation at $98^{\circ} \mathrm{C}$ for $30 \mathrm{~s}$, followed by 10 cycles at $98^{\circ} \mathrm{C}$ for $10 \mathrm{~s}, 65^{\circ} \mathrm{C}$ for $30 \mathrm{~s}$, and $72^{\circ} \mathrm{C}$ for $30 \mathrm{~s}$, with a final extension at $72^{\circ} \mathrm{C}$ for 5 min. Finally, all PCR products were quantified by Quant-iT TM dsDNA HS Reagent and pooled together. High-throughput sequencing analysis of bacterial rRNA genes was performed on the purified, pooled sample using the Illumina HiSeq 2500 platform $(2 \times 250$ paired ends $)$ at Biomarker Technologies Corporation, Beijing, China.

\subsection{Data analysis}

To obtain optimized sequences, the original data were filtered using Trimmomatic (version 0.33), merged using FLASH (version 1.2.7), and chimeric reads were removed in UCHIME (version 4.2). The optimized sequences were then clustered to obtain operational taxonomic units (OTUs) with $97 \%$ similarity using UCLUST in QIIME (v1.8.0). Species were then classified according to the sequence composition of the OTUs. Taxonomy was assigned for each phylotype based on the SILVA database (release 132) for bacteria and the UNITE database (v7.0) for fungi. Based on the OTU analysis, taxonomic analysis was performed on samples at various taxonomic levels to obtain the phylum, class, order, family, genus, and species. Alpha diversity analysis was used to obtain the species diversity for soils of different origins. Chao1 and Shannon indexes of each sample were statistically calculated to $97 \%$ similarity. Principal component analysis (PCA) and permutational multivariate analysis of variance (PERMANOVA) were used to analyze the effects of soil origin on the composition of the bacterial and fungal community at the OTU level based on Bray-Curtis distance.

Correlation networks were selected to study the correlation of the soil microbial community at the genus level. First, the correlation matrix of the genus for which the relative abundance exceeded $0.1 \%$ was calculated using the Spearman correlation analysis (psych package in R. v.4.0.2). Then, Gephi 0.9 .2 software was used to visualize the bacterial and fungal network and obtain the network structure. One node represented one genus type. The size of the node indicated the relative abundance of the genus. The color of the line between nodes indicates the positive and negative correlation of different genera.

One-way ANOVA and $t$-tests were used to test the effects of soil origin on plant and soil characteristics $(P<0.05)$. The data were first tested for normality with Kolmogorov-Smirnov procedures (Lilliefors) and homogeneity with Levene's test. One-way ANOVA [Duncan's post-hoc tests (normal), Tamhane (non-normal)] and $t$-tests were performed on data that obeyed the normal distribution. For data that did not conform to the normal distribution, $\log (X+1)$ conversion was performed. If it still did not obey the normal distribution, the Kruskal-Wallis Test $(\mathrm{H})$ was used to perform a non-parametric test.

\section{Results}

\subsection{Plant biomass}

For the first growth period, the shoot biomass of Panicum virgatum (Pv) was significantly lower when planted in earlysuccession ( $E)$, middle-succession (M), and late-succession (L) soils than in exotic species (Exo) soils (Fig. 2a). The shoot biomass of $\mathrm{Pv}$ was significantly higher when planted in $\mathrm{E}$ soils than in $M$ and $L$ soils (Fig. 2a). For the second growth period, the shoot biomass of $\mathrm{Pv}$ was significantly lower when planted in Exo-Sv and Exo-Bi soils than in Exo-Pv soils (Fig. 2b).

For the first growth period, the shoot biomass was significantly higher when Setaria viridis (Sv) and Artemisia gmelinii $(\mathrm{Ag})$ were planted in their own soils than in Exo soils. In comparison, the shoot biomass of Bothriochloa ischemum (Bi) was significantly lower when planted in its own soils than in Exo soils (Fig. 3a). For the second growth period, the shoot biomass of Sv was significantly higher when planted in E-Sv soils than in E-Pv soils. The biomass of Ag was significantly higher when planted in M-Ag soils than in M-Pv soils. The biomass of $\mathrm{Bi}$ was significantly higher when planted in $\mathrm{L}-\mathrm{Bi}$ soils than in L-Pv soils (Fig. 3b).

\subsection{Plant $\mathrm{C}, \mathrm{N}$, and $\mathrm{P}$ concentrations}

Nitrogen and phosphorus (except E) concentrations of the shoot and root of $\mathrm{Pv}$ planted in the three native species soils were, overall, lower than those planted in Exo soils (Table 2). For the second growth period, nitrogen and phosphorus concentrations in the shoots and roots of $\mathrm{Pv}$ were significantly higher when planted in Exo-Sv and Exo-Bi soils than in ExoPv soils (Table 2).

Carbon, nitrogen, and phosphorus concentrations were significantly higher in the shoots of Sv and Ag planted in their own soils than in Exo soils (Table 3). The phosphorus concentration was higher in the shoots and roots of Bi planted in Exo soils than in L soils (Table 3 ). For the second growth 

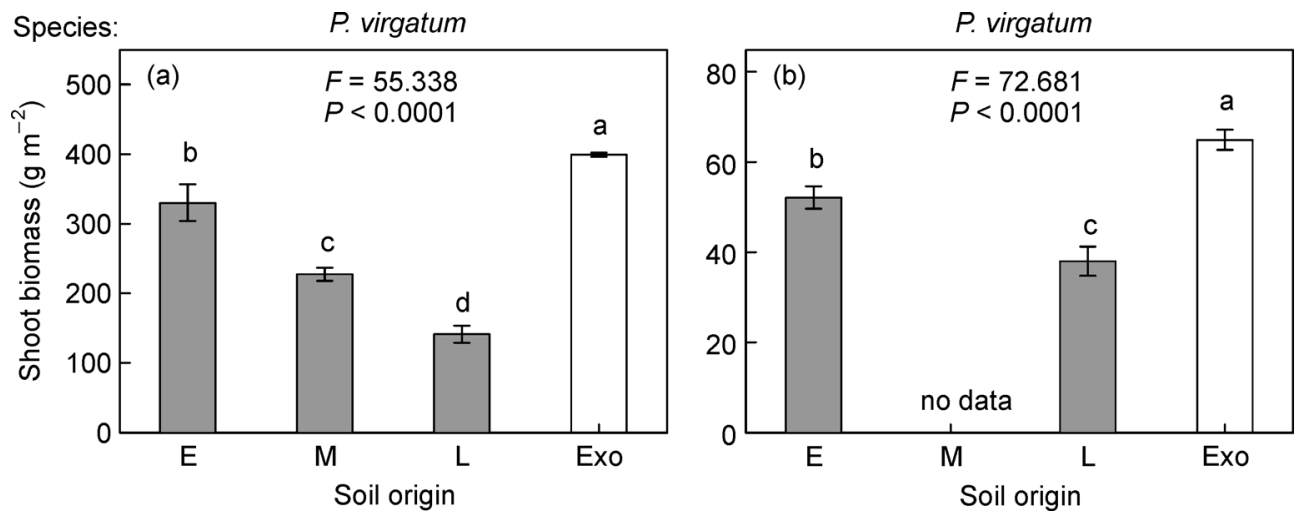

Fig. 2 Mean $( \pm \mathrm{SE})(n=4)$ of shoot biomass (a) of the exotic species Panicum virgatum (Pv) grown in pots with the soils of early-succession $(E)$, middle-succession (M), late-succession (L), and exotic (Exo) species. Mean ( $+\mathrm{SE}$ ) of shoot biomass (b) of the exotic species Panicum virgatum ( $\mathrm{Pv}$ ) grown in pots with soil of the three native species, i.e., early-succession Setaria viridis (Sv), middle-succession Artemisia gmelinii (Ag), and late-succession Bothriochloa ischemum (Bi), and exotic species Pv originated from Exo field soils. Different letters indicate significant differences among groups based on Duncan's post hoc test $(P<0.05)$. No data means that pots was accidentally damaged during planting.
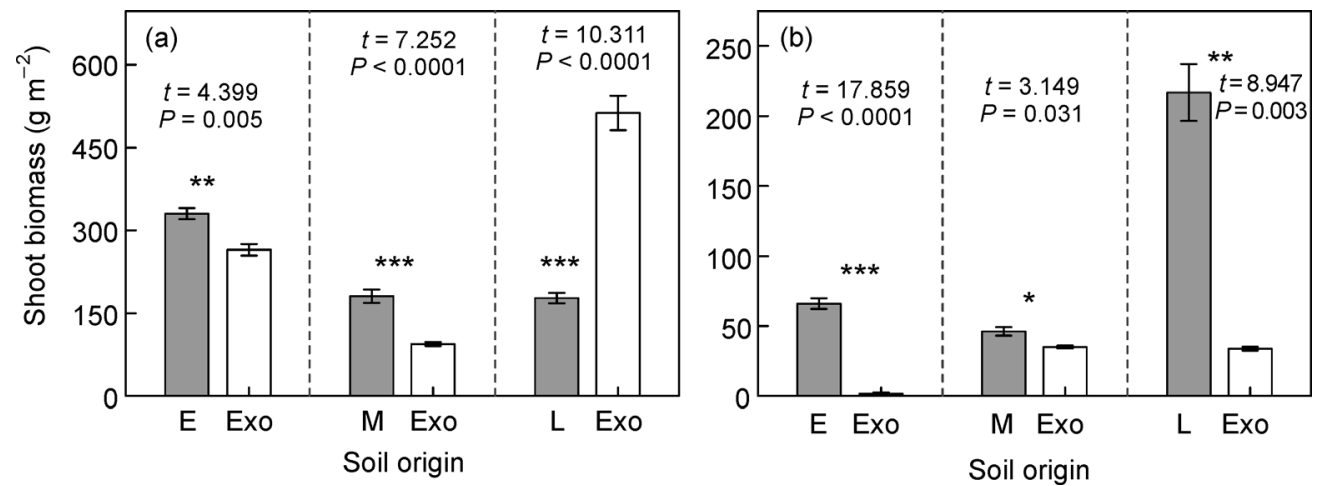

Fig. 3 Mean $(t \mathrm{SE})(n=4)$ of shoot biomass (a) of Setaria viridis (Sv) grown in pots with the field soil of early- succession (E) and exotic (Exo) species, Artemisia gmelinii (Ag) grown in pots with the field soil of middle-succession (M) and Exo species, and Bothriochloa ischemum (Bi) grown in pots with the field soil of late-succession (L) and Exo species. Mean ( \pm SE) of shoot biomass (b) of Setaria viridis (Sv) grown in pots with soils of Sv and Panicum virgatum (Pv) originating from early-succession (E) field soil, Artemisia gmelinii (Ag) grown in pots with soils of $\mathrm{Ag}$ and $\mathrm{Pv}$ originating from middle-succession $(\mathrm{M})$ field soil, and Bothriochloa ischemum (Bi) grown in pots with soils of $\mathrm{Bi}$ and $\mathrm{Pv}$ originating from late-succession (L) field soil. Notes: ${ }^{*}$, ${ }^{* *}$ and ${ }^{* * *}$ indicate significant differences at $P<0.05, P<0.01$ and $P<0.001$, respectively based on the $t$-test.

period, nitrogen and phosphorus concentrations were significantly higher in the shoots of Sv planted in E-Sv soils than in E-Pv soils (Table 3). Carbon, nitrogen, and phosphorus concentrations were significantly higher in the shoots and roots of $\mathrm{Ag}$ and $\mathrm{Bi}$ planted in their own soils than in $\mathrm{Pv}$ soils (Table 3).

\subsection{Soil chemical property}

SOC (except Exo-Sv), AP, and AN concentrations were significantly higher in Exo-Pv soils than in Exo-CK, Exo-Sv, and Exo-Bi soils (Table 1). After planting native and exotic species in native species soils, SOC, TN, TP, AP, and AN concentrations were higher in E-Sv soils than in E-CK and E$\mathrm{Pv}$ soils. The concentrations of these parameters were higher in $\mathrm{M}-\mathrm{Ag}$ soils than in $\mathrm{M}-\mathrm{CK}$ and $\mathrm{M}-\mathrm{PV}$ soils. $\mathrm{AP}$ and $\mathrm{AN}$ concentrations were higher in L-Bi soils than in L-CK and L-Pv soils (Table 4 ).

\subsection{Soil biological property}

MBC, MBN, B-G, N-AG, and A-P were higher in Exo-Pv soils than in Exo-CK, Exo-Sv, and Exo-Bi soils. Bacterial diversity (Shannon index) and fungal richness (Chao1) were higher in Exo-Sv, Exo-Bi, and Exo-Pv than in Exo-CK. There was no significant difference in these two parameters in Exo-Sv, Exo$\mathrm{Bi}$, and Exo-Pv soils (Table 5). After planting native and exotic species in native soils, MBC, MBN, B-G, N-AG, and A-P were higher in E-Sv soils than in E-CK and E-Pv soils. These parameters were higher in $\mathrm{M}-\mathrm{Ag}$ soils than in $\mathrm{M}-\mathrm{CK}$ and $\mathrm{M}-\mathrm{PV}$ 
Table 2 Mean $(t \mathrm{SE})$ of plant carbon, nitrogen, and phosphorus concentrations of Panicum virgatum (Pv) planted in soils of different origin.

\begin{tabular}{|c|c|c|c|c|c|c|}
\hline \multirow[t]{2}{*}{ Soil origin } & \multicolumn{3}{|c|}{ Shoot } & \multicolumn{3}{|c|}{ Root } \\
\hline & Carbon $\left(\mathrm{g} \mathrm{kg}^{-1}\right)$ & Nitrogen $\left(\mathrm{g} \mathrm{kg}^{-1}\right)$ & Phosphorus $\left(\mathrm{g} \mathrm{kg}^{-1}\right)$ & Carbon $\left(\mathrm{g} \mathrm{kg}^{-1}\right)$ & Nitrogen $\left(\mathrm{g} \mathrm{kg}^{-1}\right)$ & Phosphorus $\left(\mathrm{g} \mathrm{kg}^{-1}\right)$ \\
\hline$E$ & $530.24 \pm 3.17$ & $8.88 \pm 0.43 a b$ & $0.69 \pm 0.01 a$ & $384.93 \pm 1.06 a b$ & $7.43 \pm 0.24 a b$ & $0.60 \pm 0.02 a$ \\
\hline M & $539.63 \pm 21.32$ & $7.97 \pm 0.22 \mathrm{bc}$ & $0.62 \pm 0.02 b$ & $370.90 \pm 2.27 b c$ & $7.35 \pm 0.22 \mathrm{ab}$ & $0.44 \pm 0.02 c$ \\
\hline L & $526.53 \pm 4.97$ & $7.76 \pm 0.22 c$ & $0.61 \pm 0.03 b$ & $362.51 \pm 8.09 c$ & $7.19 \pm 0.12 b$ & $0.50 \pm 0.01 b$ \\
\hline Exo & $532.58 \pm 10.27$ & $9.75 \pm 0.35 a$ & $0.72 \pm 0.00 a$ & $393.28 \pm 8.29 a$ & $8.08 \pm 0.31 a$ & $0.62 \pm 0.01 a$ \\
\hline Exo-Sv & $413.43 \pm 3.48$ & $9.22 \pm 0.41$ & $1.57 \pm 0.09$ & $303.80 \pm 1.62 a$ & $5.20 \pm 0.39 a b$ & $0.90 \pm 0.02 b$ \\
\hline Exo-Bi & $404.77 \pm 8.78$ & $9.07 \pm 0.3$ & $1.49 \pm 0.06$ & $289.44 \pm 2.90 \mathrm{~b}$ & $4.51 \pm 0.11 b$ & $0.69 \pm 0.02 c$ \\
\hline Exo-Pv & $419.01 \pm 3.41$ & $9.47 \pm 0.09$ & $1.70 \pm 0.03$ & $307.17 \pm 6.73 a$ & $5.82 \pm 0.15 a$ & $1.01 \pm 0.03 a$ \\
\hline
\end{tabular}

Notes: E, early- succession field soil. M, middle- succession field soil. L, late- succession field soil. Exo, exotic species field soil. Exo-Sv, Exo-Bi and Exo-Pv, field exotic species (Exo) soil in pots were grown for Setaria viridis ( $\mathrm{Sv}$ ), Bothriochloa ischaemum (Bi) and Panicum virgatum (Pv), respectively. Different letters indicate significant differences among groups based on Duncan's post hoc test $(P<0.05)$.

Table 3 Mean $( \pm$ SE) of plant carbon, nitrogen, and phosphorus concentrations of the three native plant species, Setaria viridis (Sv), Artemisia gmelinii (Ag), and Bothriochloa ischaemum (Bi), planted in soils of different origin.

\begin{tabular}{|c|c|c|c|c|c|c|c|}
\hline \multirow[t]{2}{*}{ Species } & \multirow[t]{2}{*}{ Soil origin } & \multicolumn{3}{|c|}{ Shoot } & \multicolumn{3}{|c|}{ Root } \\
\hline & & Carbon $\left(\mathrm{g} \mathrm{kg}^{-1}\right)$ & Nitrogen $\left(\mathrm{g} \mathrm{kg}^{-1}\right)$ & Phosphorus $\left(\mathrm{g} \mathrm{kg}^{-1}\right)$ & Carbon $\left(\mathrm{g} \mathrm{kg}^{-1}\right)$ & Nitrogen $\left(\mathrm{g} \mathrm{kg}^{-1}\right)$ & Phosphorus $\left(\mathrm{g} \mathrm{kg}^{-1}\right)$ \\
\hline \multirow[t]{2}{*}{ Sv } & $E$ & $456.99 \pm 8.27^{* *}$ & $9.00 \pm 0.58^{*}$ & $0.75 \pm 0.02^{* * *}$ & $418.49 \pm 20.27$ & $6.52 \pm 0.29$ & $0.68 \pm 0.01^{* *}$ \\
\hline & Exo & $408.57 \pm 7.61$ & $7.17 \pm 0.25$ & $0.56 \pm 0.02$ & $408.36 \pm 13.41$ & $5.74 \pm 0.11$ & $0.44 \pm 0.03$ \\
\hline \multirow[t]{2}{*}{$\mathrm{Ag}$} & M & $451.97 \pm 0.57^{*}$ & $17.08 \pm 0.62^{*}$ & $1.55 \pm 0.08^{\star *}$ & $441.85 \pm 10.98^{\star *}$ & $7.00 \pm 0.62$ & $1.33 \pm 0.04$ \\
\hline & Exo & $443.10 \pm 2.49$ & $15.19 \pm 0.27$ & $0.95 \pm 0.06$ & $376.57 \pm 3.93$ & $5.13 \pm 0.72$ & $1.40 \pm 0.19$ \\
\hline \multirow[t]{2}{*}{$\mathrm{Bi}$} & L & $497.70 \pm 4.92$ & $8.58 \pm 0.18$ & $0.51 \pm 0.02^{*}$ & $336.75 \pm 16.49$ & $5.48 \pm 0.66^{*}$ & $0.36 \pm 0.01^{* *}$ \\
\hline & Exo & $501.33 \pm 7.62$ & $8.20 \pm 0.46$ & $0.62 \pm 0.04$ & $337.91 \pm 9.12$ & $3.39 \pm 0.19$ & $0.47 \pm 0.02$ \\
\hline \multirow[t]{2}{*}{ Sv } & E-Sv & $401.39 \pm 0.54^{\star *}$ & $16.75 \pm 0.27^{\star \star}$ & $0.97 \pm 0.05$ & $353.35 \pm 4.05^{\star \star}$ & $5.98 \pm 0.27$ & $0.65 \pm 0.03$ \\
\hline & $\mathrm{E}-\mathrm{PV}$ & $407.36 \pm 0.73$ & $14.82 \pm 0.14$ & $0.88 \pm 0.02$ & $322.18 \pm 3.68$ & no data & no data \\
\hline \multirow[t]{2}{*}{$\mathrm{Ag}$} & $\mathrm{M}-\mathrm{Ag}$ & $425.25 \pm 1.17^{*}$ & $17.87 \pm 0.35^{\star}$ & $1.18 \pm 0.06^{\star \star *}$ & $387.49 \pm 4.48^{\star \star}$ & $8.59 \pm 0.30^{* * *}$ & $1.12 \pm 0.06^{\star *}$ \\
\hline & $M-P v$ & $415.85 \pm 2.47$ & $16.25 \pm 0.31$ & $0.75 \pm 0.03$ & $344.29 \pm 5.65$ & $5.64 \pm 0.29$ & $0.88 \pm 0.03$ \\
\hline \multirow[t]{2}{*}{$\mathrm{Bi}$} & L-Bi & $409.55 \pm 3.23^{\star *}$ & $8.76 \pm 0.16^{*}$ & $0.69 \pm 0.00^{\star *}$ & $380.47 \pm 0.55$ & $5.18 \pm 0.04^{*}$ & $0.84 \pm 0.01^{*}$ \\
\hline & $\mathrm{L}-\mathrm{Pv}$ & $388.19 \pm 1.95$ & $8.01 \pm 0.2$ & $0.55 \pm 0.02$ & $364.16 \pm 4.64$ & $2.41 \pm 0.46$ & $0.73 \pm 0.03$ \\
\hline
\end{tabular}

Notes: E, early succession field soil. M, middle succession field soil. L, later succession field soil. Exo, exotic species field soil. E-Sv and E-PV, field $\mathrm{E}$ soil in pots were grown for $\mathrm{Sv}$ and $\mathrm{Pv}$, respectively. M-Ag and $\mathrm{M}-\mathrm{Pv}$, field $\mathrm{M}$ soil in pots were grown for $\mathrm{Ag}$ and $\mathrm{Pv}$, respectively. L-Bi and L-Pv, field $\mathrm{L}$ soil in pots were grown for $\mathrm{Bi}$ and $\mathrm{PV}$, respectively. ${ }^{*},{ }^{* *}$ and ${ }^{* * *}$ indicate significant differences at $P<0.05, P<0.01$, and $P<0.001$, respectively, based on the t-test. No data means that the samples were insufficient to complete a measurement.

soils. These parameters were also higher in L-Bi soils than in L-CK and L-Pv soils (Table 5).

In all soils, the dominant bacterial phyla were Proteobacteria, Acidobacteria, Actinobacteria, and Gemmatimonadetes (Fig. 4a, c, e, g). Acidobacteria dominated Exo-Pv, Exo-CK (Fig.4a, Table S1), and E-Sv soils (Fig. 4c, Table S1).

In all soils, the dominant fungal phyla were Ascomycota, Basidiomycota, and Glomeromycota (Fig. 4b, d, f, h). Basidiomycota dominated Exo-Pv soils (Fig. 4b, Table S1).
No significant differences in bacteria and fungi were found at the phylum level in soils created by native plants and exotic plants (Pv) (Fig. 4d, e, f, g, h).

PCA and PERMANOVA showed that, compared to bare soil (-CK) (Fig. 5a-h, Table S2), all treatments showed variations in the bacterial and fungal community compositions (except for the bacterial community composition in L soils; Fig. 5d). No clear variation was detected in the composition of bacterial and fungal communities in the soils created by native 
Table 4 Mean $(t S E)$ of soil chemical properties in the soils created by the four plant species after the first growth period.

\begin{tabular}{|c|c|c|c|c|c|}
\hline Soil origin & $\mathrm{SOC}\left(\mathrm{g} \mathrm{kg}^{-1}\right)$ & $\mathrm{TN}\left(\mathrm{g} \mathrm{kg}^{-1}\right)$ & $\mathrm{TP}\left(\mathrm{g} \mathrm{kg}^{-1}\right)$ & $\mathrm{AP}\left(\mathrm{mg} \mathrm{kg}^{-1}\right)$ & AN $\left(\mathrm{mg} \mathrm{kg}^{-1}\right)$ \\
\hline Exo-CK & $4.91 \pm 0.02 b$ & $0.55 \pm 0.0$ & $0.57 \pm 0.02 a$ & $0.99 \pm 0.08 d$ & $18.82 \pm 0.45 b$ \\
\hline Exo-Sv & $5.20 \pm 0.10 a$ & $0.56 \pm 0.01$ & $0.57 \pm 0.01 \mathrm{a}$ & $1.59 \pm 0.07 b$ & $18.78 \pm 0.23 b$ \\
\hline Exo-Bi & $5.08 \pm 0.02 \mathrm{ab}$ & $0.55 \pm 0.00$ & $0.52 \pm 0.02 b$ & $1.41 \pm 0.03 c$ & $14.99 \pm 0.91 \mathrm{c}$ \\
\hline Exo-Pv & $5.23 \pm 0.06 a$ & $0.56 \pm 0.01$ & $0.57 \pm 0.01 a$ & $1.71 \pm 0.01 a$ & $21.82 \pm 0.36 a$ \\
\hline E-CK & $5.17 \pm 0.14 b$ & $0.59 \pm 0.01 b$ & $0.50 \pm 0.01 b$ & $1.16 \pm 0.110 b$ & $20.13 \pm 0.18 c$ \\
\hline E-Sv & $5.68 \pm 0.06 a$ & $0.63 \pm 0.01 a$ & $0.54 \pm 0.01 a$ & $1.56 \pm 0.06 a$ & $23.22 \pm 0.27 a$ \\
\hline E-Pv & $5.29 \pm 0.10 b$ & $0.62 \pm 0.01 a$ & $0.51 \pm 0.01 \mathrm{~b}$ & $1.18 \pm 0.14 b$ & $21.85 \pm 0.49 b$ \\
\hline $\mathrm{M}-\mathrm{CK}$ & $4.75 \pm 0.19 b$ & $0.57 \pm 0.01 \mathrm{ab}$ & $0.56 \pm 0.01 \mathrm{ab}$ & $0.84 \pm 0.03 c$ & $29.06 \pm 0.15 c$ \\
\hline $\mathrm{M}-\mathrm{Ag}$ & $5.16 \pm 0.04 a$ & $0.59 \pm 0.01 \mathrm{a}$ & $0.58 \pm 0.00 a$ & $1.65 \pm 0.05 a$ & $33.96 \pm 0.10 a$ \\
\hline$M-P v$ & $5.01 \pm 0.06 \mathrm{ab}$ & $0.55 \pm 0.01 b$ & $0.53 \pm 0.013 b$ & $1.01 \pm 0.04 b$ & $31.15 \pm 0.33 b$ \\
\hline L-CK & $4.58 \pm 0.06 b$ & $0.51 \pm 0.01$ & $0.47 \pm 0.01$ & $0.98 \pm 0.09 b$ & $29.21 \pm 0.59 c$ \\
\hline L-Bi & $5.06 \pm 0.08 a$ & $0.53 \pm 0.01$ & $0.46 \pm 0.01$ & $1.77 \pm 0.06 a$ & $34.05 \pm 0.38 a$ \\
\hline L-Pv & $4.89 \pm 0.06 a b$ & $0.52 \pm 0.01$ & $0.45 \pm 0.01$ & $0.79 \pm 0.07 b$ & $30.65 \pm 0.23 b$ \\
\hline
\end{tabular}

Notes: Exo-CK, E-CK, M-CK, and L-CK, no plants were prepared. Exo-Sv, Exo-Bi, and Exo-Pv, field Exo soil in pots were grown for Setaria viridis (Sv), Bothriochloa ischaemum (Bi), and Panicum virgatum (Pv), respectively. E-Sv and E-Pv, field E soil in pots were grown for Sv and Pv, respectively. $\mathrm{M}-\mathrm{Ag}$ and $\mathrm{M}-\mathrm{Pv}$, field $\mathrm{M}$ soil in pots was grown for $\mathrm{Ag}$ and $\mathrm{Pv}$, respectively. $\mathrm{L}-\mathrm{Bi}$ and $\mathrm{L}-\mathrm{Pv}$, field $\mathrm{L}$ soil in pots were grown for $B i$ and $\mathrm{Pv}$, respectively. SOC, soil organic carbon. TN, soil total nitrogen. TP, soil total phosphorus. AP, soil available phosphorus. AN, soil available nitrogen. Different letters indicate significant differences among groups based on Duncan's post hoc test $(P<0.05)$.

species compared to the soils created by the exotic species (Pv) (Fig. 5a, b, d, e, g, h, Table S2), with the exception of E-Sv and E-Pv soils for bacterial community composition (Fig. 5c, Table S2) and M-Ag and M-Pv soils for fungal community composition (Fig. 5f, Table S2).

\subsection{Correlation networks of the soil microbial community}

Based on the relationship networks, bacteria captured 1210 edges, 1523 edges, 1455 edges, and 1434 edges, while fungi captured 61 edges, 98 edges, 70 edges, and 97 edges, for Exo-CK, Exo-Sv, Exo-Bi, and Exo-Pv, respectively (Fig. S1a, Table S3). Bacteria captured 1612 edges, 1484 edges, and 1413 edges, while fungi captured 119 edges, 115 edges, and 114 edges, for E-CK, E-Sv, and E-Pv, respectively (Fig. S1b, Table S3). Bacteria captured 1026 edges, 1090 edges, and 1195 edges, while fungi captured 101 edges, 94 edges, and 96 edges, for M-CK, M-Ag and M-Pv, respectively (Fig. S1c, Table S3). Bacteria captured 1027 edges, 1065 edges, and 1388 edges, while fungi captured 73 edges, 123 edges, and 169 edges, for L-CK, L-Bi, and L-Pv, respectively (Fig. S1d, Table S3).

\section{Discussion}

\subsection{Performance of exotic species}

Our results demonstrated that exotic species could success- fully invade native plant community soil but did not perform better during growth in the native plant community soil than in their own soil. This result confirmed our first hypothesis. Exotic and native species are heterogeneous (Pearse et al., 2019). Consequently, the original native soil environment has a competitive repulsive effect on exotic species, which hinders the invasion of exotic species (Cavender-Bares et al., 2009).

The availability of soil resources and soil microorganisms is considered to be crucial for plant growth (Valliere et al., 2019; Zhang et al., 2020). In our study, the soil available nutrient and soil microbial biomass levels were relatively lower in soils disturbed by native species than those in soils disturbed by exotic species. The exotic species invasion disturbed the soil balance by altering the soil microbial composition and diversity (Zhang et al., 2020). The relatively high soil microbial activity provides the basic conditions for releasing available nutrients in the soil, thereby facilitating their absorption and utilization by plants (Kristiina et al., 2014).

Our study found that soil microbial diversity ( $\alpha$ and $\beta$ ) showed no significant difference among the exotic species soils disturbed by different plant species. In contrast, the soils disturbed by exotic species had higher abundance of Acidobacteria (bacteria) and Basidiomycota (fungi) at the phylum level. Acidobacteria use nitrite as a nitrogen source, respond to soil nutrient availability, and have a variety of active transporters (Kielak et al., 2016). Consequently, these bacteria influence the circulation of nutrient elements (especially nitrogen) in the soil. Basidiomycota are typically saprotrophic and are very sensitive to the decomposition of 


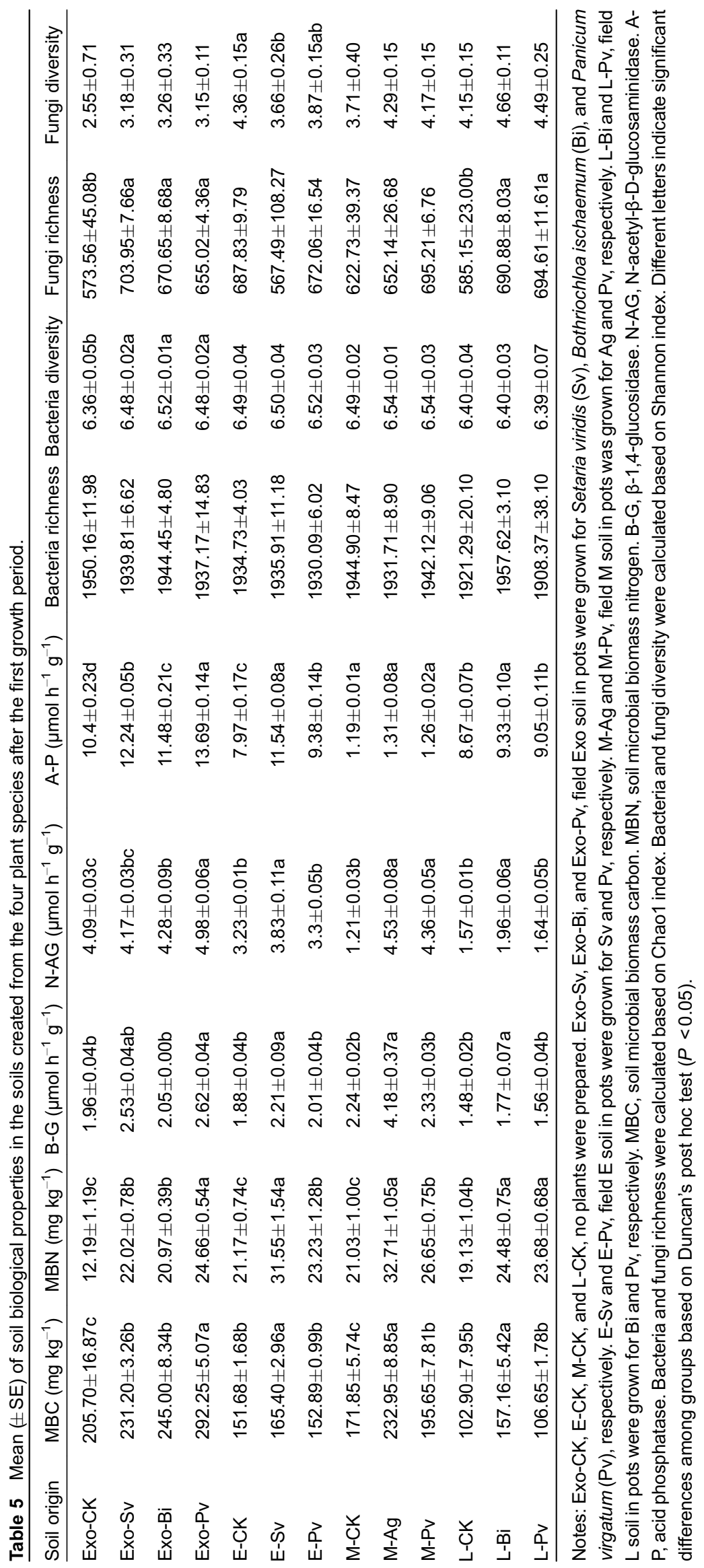


organic matter (Curlevski et al., 2010). In addition, in the bacterial correlation network, soil disturbance by exotic species had fewer edges than that of soils disturbed by native species, but had a higher ratio of positive:total correlation edges. These results demonstrate that strong coexistence exists in the interactions between bacterial groups, with low differentiation among bacterial groups. This phenomenon indicates that competition for resources is not fierce in soil disturbed by exotic species. In parallel, higher soil nutrient content stimulates the transformation of the relationship between species in microbial communities (Loranger-Merciris et al., 2006). This special network of bacteria might accelerate the growth of plants to a certain level (Tian et al., 2018).

Previous studies showed that the photosynthetic rate, growth rate, and resource competitiveness of plants are positively correlated with plant nitrogen and phosphorus concentrations (Yang et al., 2015). Our study demonstrated that plants cultivated in native plant soils and soils disturbed by native species had lower nitrogen and phosphorus concentrations. Thus, the biomass of exotic species was lower upon cultivation in soils disturbed by native species than in soils disturbed by exotic species.

Additionally, our study confirmed that the invasion advantage of exotic species is higher in the early-succession stage soil and lower in the late-succession stage soil, confirming our third hypothesis. The success of exotic species invasion is usually attributed to higher competitiveness (Zhang and van Kleunen, 2019). The soil of fast-growing plant communities is more conducive to plant colonization (Baxendale et al., 2014). Early successional species are pioneer species, which grow fast; consequently, the soil is easily colonized by exotic species. In comparison, late successional species are generally large and grow slowly. In addition, relatively complex network relationships of bacteria and fungi were detected in soils disturbed by early successional species (edges and positive edges). This complex microbial network promotes soil nutrient cycling and plant growth (Tian et al., 2018). Nutrient levels were lower in soil disturbed by species during the later stage of succession. Thus, there is less nutrients in the soil at this later stage that could be directly used by plants. This phenomenon was confirmed by the fact that exotic species planted in the soil of early successional species and soil created by early successional species had relatively higher nitrogen and phosphorus concentrations of plants.

Our research studied the invasion ability and advantage of exotic species on the basis of soils at different succession stages. In addition, the roles of plant nutrients, soil nutrients, and soil microbial composition and diversity in promoting plant invasion were studied. Our research helps to strengthen our understanding of invasion ecology. However, the invasion of exotic species significantly affects soil microorganisms (Chen et al., 2020; Zhang et al., 2020). The composition and diversity of soil microorganisms, as well as the functional flora, are affected by plant root exudates and litter (Vogelsang and Bever, 2009; Shannon et al., 2014; Piper et al., 2015). The change in soil microflora has a certain feedback effect on the soil environment as well as physical and chemical properties (such as water, air, and temperature) (Duda et al., 2003). However, this study only provides data for indoor greenhouse experiments, as field experiments were not performed. Therefore, in future research, a combination of greenhouse experiments and field experiments should be used to study the invasion and invasion capabilities of exotic species, as well as to explore the effects of soil nutrients, soil microorganisms, plant root exudates, and litter on exotic species and their invasion mechanism. Moreover, a comprehensive analysis of the interaction among invasive plants, soil microorganisms, and soil ecosystem processes should be conducted.

\subsection{Performance of native species}

Early- and mid-succession species did not perform better when grown in exotic species soil than when grown in their own soil. The balanced symbiotic relationships between the original plants and soil is destroyed after invasion (Mangla and Callaway, 2007), resulting in the formation of a soil environment that is conducive to the growth of the exotic species (Pearse et al., 2019). Zubek et al. (2016) showed that the metabolites produced by invasive species have novel effects on microorganisms in the soil. These secondary compounds directly hinder the roots of replanted plants from colonizing (Callaway et al., 2008).

Furthermore, this study demonstrates that exotic species soil has a high species-specific effect on replanted plants. Unlike early- and mid-succession species, the late successional species obtained a greater advantage in the field soil of exotic species than in their own soil. Our results indicate that the recovery of plants depends on the stage of succession; in other words, the late successional species can be restored after exotic species are removed, whereas the recovery of early and middle successional species is difficult. Exotic species have clear underground effects (Zhang et al., 2020). For example, after long-term disturbance by exotic species, the soil has relatively high amounts of available nutrient pools, complemented with higher microbial activity in soils of early- to mid-succession species than in soil of late-succession species. Late successional species dominate in replacement succession and have a strong ability to compete for nutrition under the action of soil microorganisms in a new environment (Li et al., 2015). In our study, late successional species had a higher phosphorus acquisition ability when grown in the field soil of exotic species than in their own soil. High phosphorus acquisition accelerates protein synthesis in plants. Therefore, in a new environment, late-succession species are more able to enhance the absorption of nutrients, and hence increase biomass, than early- and mid-succession species.

Interestingly, although the three native species can recover after the removal of exotic species, recoverability is lower when they are grown in soil disturbed by exotic species than when they are grown in their own soil (experiment 2). Differences in abiotic and biotic soil conditions strongly influence plant growth (Bever et al., 1997). In our study, soil 


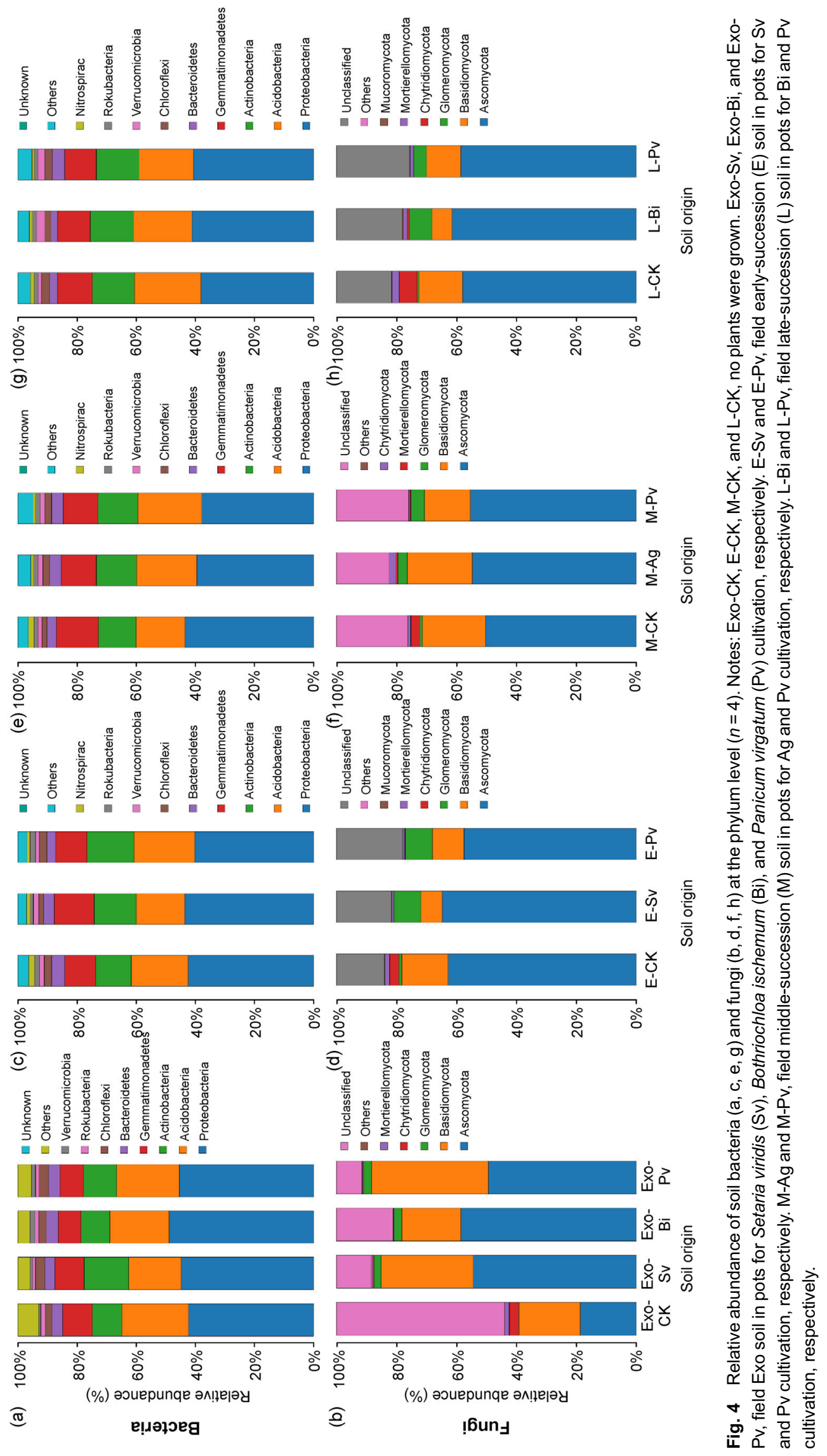



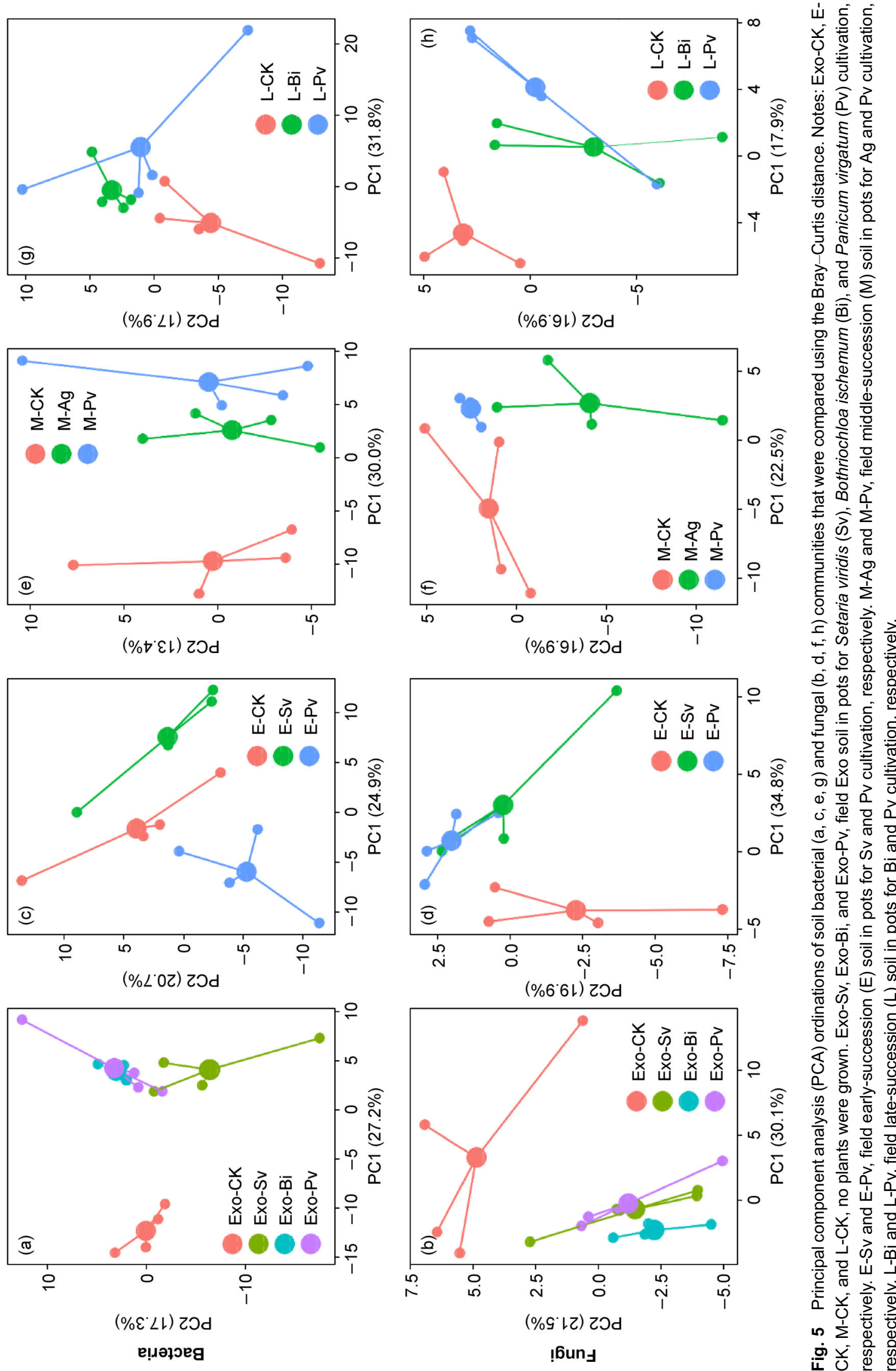

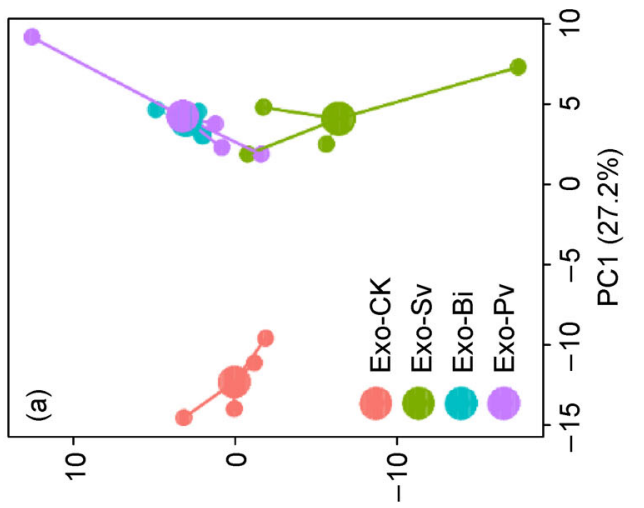

(\%\& ८ا) Zวd

е!ฺวюวея

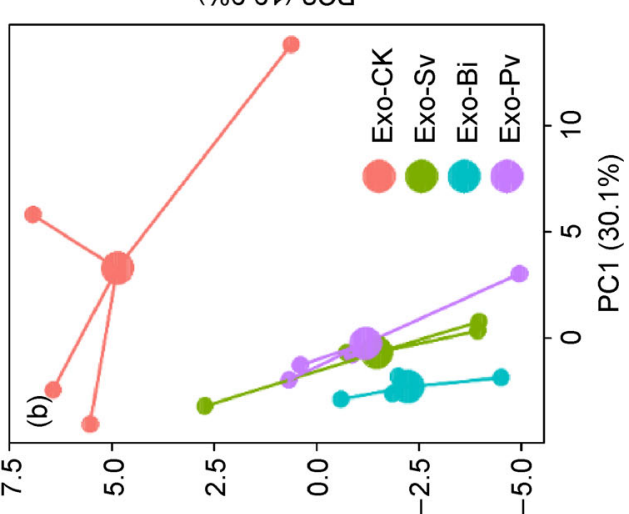

(\%

!́uny

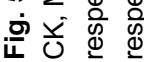


disturbed by exotic species had lower soil nutrient content and microbial activity. This phenomenon might cause a high degree of heterogeneity in the growth of replanted plants (Chen et al., 2020). The combination of low fertility and low enzyme activity creates a new environment in which species must adapt to survive. Thus, low soil nutrient content did not allow replanted plants to produce high biomass.

Plant-soil feedback confirmed that biological parameters exert an effect within months (Bever et al., 1997). Exotic species secrete various allelochemicals into the soil, which inhibit growth of bacteria that are beneficial to plant growth (Favaretto et al., 2011). Additionally, they secrete soil pathogens (Mangla and Callaway, 2007) that affect the growth of native plants. However, in the process of native species recovery after removal of exotic species, it is possible that (1) the accumulation of soil microorganisms actually impeded the growth of native species, or (2) growth of the beneficial microorganisms conducive to the growth of native species was inhibited. Thus, future studies must focus on elucidating these mechanisms.

In this study, the diversity and composition of bacteria and fungi in the soil were not significantly impacted by native and exotic species soils. However, the complexity of the microbial correlation network differed among soils. Plant growth was mainly determined by the extent to which microorganisms were positively correlated. Although microorganisms were still correlated in soil created by exotic species, the number of positive correlation edges for bacteria and fungi was lower in these soils than that in soil that created by native species (except for the fungus correlation network in soil created by late-succession species). Thus, in soils disturbed by exotic species, microorganisms have a weak symbiotic relationship. There is a certain differentiation phenomenon and a certain competitive relationship in resource utilization. This complex relationship in the microbial community is closely related to soil nutrient levels (Loranger-Merciris et al., 2006). Nutrient levels are lower in soils disturbed by exotic species, which affects the relationship of the microbial community, thus restricting plant growth.

In addition, species that grow in soils created by exotic species have lower carbon, nitrogen, and phosphorus concentrations, particularly for plant shoots. This difference in plant nutrient concentrations reflects the dynamic balance between the soil nutrient supply and plant nutrient demand (Yang et al., 2015). Plants better adapted to soils with low nutrient levels might have low nutrient contents, as demonstrated in our study, wherein nutrients in soils created by exotic species were lower overall.

Our research emphasizes that compared to late-succession species, early- and mid-succession species exhibit lower recoverability. Our research selected three typical dominant succession species in the Loess Plateau of China as the research objects and focused on evaluating the recovery ability of plants in the three succession stages. We believe that this study gives a good representation of the current state of grasslands in arid and semi-arid regions of China. However, invasion by exotic species is global (Guido and Pillar, 2017). Therefore, this local-scale research may be restricted, and our research conclusions cannot be extended to a regional or global scale. The invasion by exotic species is significantly affected by climatic conditions (Hejda et al., 2009), and on a larger scale, the restoration of native species after the removal of exotic species has not yet been effectively recognized. Therefore, it is necessary to strengthen the research on the restoration of native species in different regions in future research to evaluate the recoverability and effects of native species under different climatic conditions.

\section{Conclusion}

We examined the invasibility and recoverability of a plant community following invasion across succession through a two-year glasshouse experiment. The results confirmed our hypothesis that exotic species can smoothly invade native community soil but cannot perform better while growing in the native community soil than in their own soils, and the invasibility of a native plant community is higher in the soils of late successional species and lower in the soils of earlyand mid-succession species. Meanwhile, the late successional species exhibited stronger recoverability than earlyand mid-succession species in field exotic species soils after exotic species removal. However, after the soil was disturbed by exotic species, all the three native species showed weak recoverability. Our study provided novel insights on soil and plant characteristics during plant invasion and restoration, strengthening our understanding of invasion and restoration ecology. Further studies are needed to determine the invasion and recovery mechanisms. Additionally, there is an urgent need to perform more experiments in different climate zones and at larger spatial scales to assess the invasion and restoration ability and effects.

\section{Acknowledgments}

We thank everyone who assisted with this work, including the experimental design, data collection and analysis, and writing of the manuscript. This research were funded by the National Natural Science Foundation of China (41907409 and 41771557), and Special Scientific Research Project of Education Department of Shaanxi Provincial Government (19JK0524).

\section{Author contributions}

H.X., Z.A., and S.X. designed the experiment; H.X., G.B., M.G., and Q.Q. analyzed the data; H.X. and Z.A. wrote the manuscript. All authors made important contributions to the manuscript, and approved publication.

\section{Conflict of interest statement}

The authors declare that they have no conflict of interest. 


\section{Electronic supplementary material}

Supplementary material is available in the online version of this article at https://doi.org/10.1007/s42832-021-0100-8 and is accessible for authorized users.

\section{References}

Baxendale, C., Orwin, K.H., Poly, F., Pommier, T., Bardgett, R.D., 2014. Are plant-soil feedback responses explained by plant traits? New Phytologist 204, 408-423.

Bever, J.D., Westover, K.M., Antonovics, J., 1997. Incorporating the soil community into plant population dynamics: theutility of the feedback approach. Journal of Ecology 85, 561-573.

Bremner J., 1982. Nitrogen-Total. In: Page, A.L., Miller, R.H., Keaney, D.R., eds. Methods of Soil Analysis. American Society of Agronomy, Madison, Wisconsin, pp. 532-535.

Callaway, R.M., Cipolini, D., Barto, K., Thelen, G.C., Hallett, S.G., Prati, D., Stinson, K., Klironomos, J., 2008. Novel weapons: invasive plant suppresses fungal mutualists in American but not in its native Europe. Ecology 89, 1043-1055.

Cavender-Bares, J., Kozak, K.H., Fine, P.V.A., Kembel, S.W., 2009. The merging of community ecology and phylogenetic biology. Ecology Letters 12, 693-715.

Chen, E., Liao, H., Chen, B., Peng, S., 2020. Arbuscular mycorrhizal fungi are a double-edged sword in plant invasion controlled by phosphorus concentration. New Phytologist 226, 295-300.

Curlevski, N.J.A., Xu, Z., Anderson, I.C., Cairney, J.W.G., 2010. Converting Australian tropical rainforest to native Araucariaceae plantations alters soil fungal communities. Soil Biology \& Biochemistry 42, 14-20.

Divisek, J., Chytry, M., Beckage, B., Gotelli, N.J., Lososová, Z., Pyšek, P., Richardson, D.M., Molofsky, J., 2018. Similarity of introduced plant species to native ones facilitates naturalization, but differences enhance invasion success. Nature Communications 9, 4631.

Duda, J.J., Freeman, D.C., Emlen, J.M., Belnap, J., Kitchen, S.G., Zak, J.C., Sobek, E., Tracy, M., Montante, J., 2003. Differences in native soil ecology associated with invasion of the exotic annual chenopod, Halogeton glomeratus. Biology and Fertility of Soils 38 , 72-77.

Favaretto, A., Scheffer-Basso, S.M., Felini, V., Zoch, A.N., Carneiro, C.M., 2011. Growth of white clover seedlings treated with aqueous extracts of leaf and root of tough lovegrass. Revista Brasileira De Zootecnia-Brazilian Journal of Animal Science 40, 1168-1172.

Flory, S.L., Clay, K., 2009a. Invasive plant removal method determines native plant community responses. Journal of Applied Ecology 46, 434-442.

Flory, S.L., Clay, K., 2009b. Effects of roads and forest successional age on experimental plant invasions. Biological Conservation 142, 2531-2537.

Guido, A., Pillar, V.D., 2015. Are removal experiments effective tools for assessing plant community resistance and recovery from invasion? Journal of Vegetation 26, 608-613.

Guido, A., Pillar, V.D., 2017. Invasive plant removal: assessing community impact and recovery from invasion. Journal of Applied Ecology 54, 1230-1237.

Hejda, M., Pysek, P., Jarosik, V., 2009. Impact of invasive plants on the species richness, diversity and composition of invaded communities. Journal of Ecology 97, 393-403.

Kardol, P., Bezemer, T. M., van der Putten, W. H., 2006. Temporal variation in plant-soil feedback controls succession. Ecology Letters 9, 1080-1088.

Karhu, K., Auffret, M.D., Dungait, J.A.J., Hopkins, D.W., Prosser, J.I., Singh, B.K., Subke, J.A., Wookey, P.A., Ågren, G.I., Sebastià, M.T., Gouriveau, F., Bergkvist, G., Meir, P., Nottingham, A.T., Salinas, N., Hartley, I.P., 2014. Temperature sensitivity of soil respiration rates enhanced by microbial community response. Nature 513 , 81-84.

Kettenring, K.M., Adams, C.R., 2011. Lessons learned from invasive plant control experiments: a systematic review and meta-analysis. Journal of Applied Ecology 48, 970-979.

Kielak, A.M., Barreto, C.C., Kowalchuk, G.A., van Veen, J.A., Kuramae, E.E., 2016. The Ecology of Acidobacteria: Moving beyond genes and genomes. Frontiers in Microbiology 7, 744.

Krishna, M., Gupta, S., Delgado-Baquerizo, M., Morriën, E., Garkoti, S.C., Chaturvedi, R., Ahmad, S., 2020. Successional trajectory of bacterial communities in soil are shaped by plant-driven changes during secondary succession. Scientific Reports 10, 9864.

Kristiina, K., Auffret, M. D., Dungait, J. A. J., Hopkins, D. W., Prosser, J. I., Singh, B. K., Jens-Arne, S., Wookey, P. A., Agren, G. R. I., Maria-Teresa, S., 2014. Temperature sensitivity of soil respiration rates enhanced by microbial community response. Nature 513 , 81-84.

Li, S., Cadotte, M.W., Meiners, S.J., Hua, Z., Jiang, L., Shu, W., 2015. Species colonisation, not competitive exclusion, drives community overdispersion over long-term succession. Ecology Letters 18, 964-973.

Loranger-Merciris, G., Barthes, L., Gastine, A., Leadley, P., 2006. Rapid effects of plant species diversity and identity on soil microbial communities in experimental grassland ecosystems. Soil Biology \& Biochemistry 38, 2336-2343.

Lososova, Z., de Bello, F., Chytry, M., Kühn, I., Pyšek, P., Sádlo, J., Winter, M., Zelený, D., 2015. Alien plants invade more phylogenetically clustered community types and cause even stronger clustering. Global Ecology and Biogeography 24, 786-794.

Love, J.P., Anderson, J.T., 2009. Seasonal effects of four control methods on the invasive morrow's honeysuckle (Lonicera morrowii) and initial responses of understory plants in a southwestern pennsylvania old field. Restoration Ecology 17, 549-559.

Ma, Y., An, Y., Shui, J., Sun, Z., 2011. Adaptability evaluation of switchgrass (Panicum virgatum L.) cultivars on the Loess Plateau of China. Plant Science 181, 638-643.

Mangla, S., Callaway, R.M., 2007. Exotic invasive plant accumulates native soil pathogens which inhibit native plants. Journal of Ecology 96, 58-67.

McLaughlin, S.B., Adams Kszos, L., 2005. Development of switchgrass (Panicum virgatum) as a bioenergy feedstock in the United States. Biomass and Bioenergy 28, 515-535.

Murugan, R., Beggi, F., Prabakaran, N., Maqsood, S., Joergensen, R. G., 2020. Changes in plant community and soil ecological 
indicators in response to Prosopis juliflora and Acacia mearnsii invasion and removal in two biodiversity hotspots in Southern India. Soil Ecology Letters 2, 61-72.

Nelson, D., Sommers, L., 1982. Total carbon, organic carbon and organic matter, In: Weaver, R.W., Angle, S., Bottomley, P., Bezdicek, D., Smith, S., Tabatabai, A., Wollum, A., eds. Methods of Soil Analysis Part 2. Chemical and Microbial Properties. American Society of Agronomy, Soil Science Society of America, Madison, Wisconsin

Olsen, S.R., Sommers, L.E., 1982. Phosphorus. in: Weaver, R.W., Angle, S., Bottomley, P., Bezdicek, D., Smith, S., Tabatabai, A., Wollum, A., eds. Methods of Soil Analysis Part 2. Chemical and Microbiological Properties, 2nd ed. American Society of Agronomy, Madison (WI). American Society of Agronomy, Soil Science Society of America, Madison, Wisconsin

Pearse, I.S., Sofaer, H.R., Zaya, D.N., Spyreas, G., 2019. Non-native plants have greater impacts because of differing per-capita effects and nonlinear abundance-impact curves. Ecology Letters 22, 1214-1220.

Piper, C.L., Siciliano, S.D., Winsley, T., Lamb, E.G., 2015. Smooth brome invasion increases rare soil bacterial species prevalence, bacterial species richness and evenness. Journal of Ecology 103, 386-396.

Saiya-Cork, K.R., Sinsabaugh, R.L., Zak, D.R., 2002. The effects of long term nitrogen deposition on extracellular enzyme activity in an Acer saccharum forest soil. Soil Biology \& Biochemistry 34, 1309 1315.

Schade, J.D., Kyle, M., Hobbie, S.E., Fagan, W.F., Elser, J.J., 2003. Stoichiometric tracking of soil nutrients by a desert insect herbivore. Ecology Letters 6, 96-101.

Shannon, S.M., Bauer, J.T., Anderson, W.E., Reynolds, H.L., 2014. Plant-soil feedbacks between invasive shrubs and native forest understory species lead to shifts in the abundance of mycorrhizal fungi. Plant and Soil 382, 317-328.

Tian, J., He, N.P., Kong, W.D., Deng, Y., Feng, K., Green, S.M., Wang,
X., Zhou, J., Kuzyakov, Y., Yu, G., 2018. Deforestation decreases spatial turnover and alters the network interactions in soil bacterial communities. Soil Biology \& Biochemistry 123, 80-86.

Valliere, J.M., Escobedo, E.B., Bucciarelli, G.M., Sharifi, M.R., Rundel, P.W., 2019. Invasive annuals respond more negatively to drought than native species. New Phytologist 223, 1647-1656.

Vance, E.D., Brookes, P.C., Jenkinson, D.S., 1987. An extraction method for measuring soil microbial biomass C. Soil Biology \& Biochemistry 19, 703-707.

Vogelsang, K.M., Bever, J.D., 2009. Mycorrhizal densities decline in association with nonnative plants and contribute to plant invasion. Ecology 90, 399-407.

Wang, R.Z., 2002. Photosynthetic pathway types of forage species along grazing gradient from the songnen grassland, northeastern china. Photosynthetica 40, 57-61.

Yang, L., Jiang, M., Zhu, W., Han, L., Qin, L., 2019. Soil bacterial communities with an indicative function response to nutrients in wetlands of Northeastern China that have undergone natural restoration. Ecological Indicators 101, 562-571.

Yang, X., Huang, Z., Zhang, K., Cornelissen, J.H.C., 2015. C:N:P stoichiometry of Artemisia species and close relatives across northern China: unravelling effects of climate, soil and taxonomy. Journal of Ecology 103, 1020-1031.

Zhang, H., Goncalves, P., Copeland, E., Qi, S.S., Dai, Z.C., Li, G.L., Wang, C.Y., Du, D.L., Thomas, T., 2020. Invasion by the weed Conyza canadensis alters soil nutrient supply and shifts microbiota structure. Soil Biology \& Biochemistry 143, 107739.

Zhang, Z., van Kleunen, M., 2019. Common alien plants are more competitive than rare natives but not than common natives. Ecology Letters 22, 1378-1386.

Zubek, S., Majewska, M.L., Baszkowski, J., Stefanowicz, A.M., Nobis, M., Kapusta, P., 2016. Invasive plants affect arbuscular mycorrhizal fungi abundance and species richness as well as the performance of native plants grown in invaded soils. Biology and Fertility of Soils $52,879-893$. 